Proceeding Paper

\title{
Socioeconomic and Climatic Impacts of Photovoltaic Systems Operating High-Efficiency Irrigation Systems: A Case Study of the Government Subsidy Scheme for Climate-Smart Agriculture in Punjab, Pakistan ${ }^{\dagger}$
}

\author{
Faakhar Raza ${ }^{1}$, Muhammad Tamoor ${ }^{2, *(D)}$ and Sajjad Miran ${ }^{3, * \mathbb{D}}$ \\ 1 Pakistan Council of Research in Water Resources, Regional Director, Lahore 54000, Pakistan; \\ faakharraza@gmail.com \\ 2 Department of Electrical Engineering and Technology, Government College University Faisalabad, \\ Faisalabad 38000, Pakistan \\ 3 Department of Mechanical Engineering, University of Gujrat, Gujrat 50700, Pakistan \\ * Correspondence: phd.20.muhammadtamoor@gmail.com (M.T.); sajjad.miran@uog.edu.pk (S.M.); \\ Tel.: +92-344-4644644 (M.T.); +92-331-4957621 (S.M.) \\ + Presented at the 1st International Conference on Energy, Power and Environment, Gujrat, Pakistan, \\ 11-12 November 2021.
}

check for

updates

Citation: Raza, F.; Tamoor, M.; Miran, S. Socioeconomic and Climatic Impacts of Photovoltaic Systems Operating High-Efficiency Irrigation Systems: A Case Study of the Government Subsidy Scheme for Climate-Smart Agriculture in Punjab, Pakistan. Eng. Proc. 2021, 12, 36. https://doi.org/10.3390/engproc 2021012036

Academic Editor: Ahsan Waseem

Published: 27 December 2021

Publisher's Note: MDPI stays neutral with regard to jurisdictional claims in published maps and institutional affiliations.

Copyright: (c) 2021 by the authors Licensee MDPI, Basel, Switzerland. This article is an open access article distributed under the terms and conditions of the Creative Commons Attribution (CC BY) license (https:// creativecommons.org/licenses/by/ $4.0 /)$

\begin{abstract}
This paper presents the results of a field study conducted in the Punjab, Pakistan, to evaluate the socio-economic and climatic impact of Photovoltaic (PV) systems installed under government subsidy scheme for operating high efficiency irrigation systems (HEIS) i.e., drip and sprinkler irrigation systems. Agriculture provides livelihood to almost half of the rural population and recent energy crisis in the country has adversely affected the rural communities. Farmer's dependence on fossil fuels has significantly increased for operating irrigation systems which has resulted in high costs of agriculture production. Government of Punjab has launched a subsidy scheme to install PV systems for operating efficient drip and sprinkler irrigation systems on cost sharing basis. Photovoltaic systems having a capacity of 17.30 megawatt, were installed to operate high efficiency irrigation systems at around twenty thousand acres under this subsidy project, that has resulted in an annual saving of 0.0066 billion liters of diesel. The average capacity of installed PV systems was 9.0 kilowatt, which matched the 7.50 horse power of installed water pumps. On average, the cost of a PV system per acre was calculated to be 0.000142 billion PKR, while the cost per $\mathrm{kWp}$ was calculated to be 0.000149 billion PKR. The research results show that the installation of photovoltaic systems has increased the adoption rate of high-efficiency irrigation systems, reduced carbon dioxide emissions, and reduced the high operating costs associated with diesel powered pump systems. The primary data about on-farm agriculture and irrigation practices used in this study were collected through in-depth farmer surveys, while the secondary data information came from reports, official documents and statistics issued by the government.
\end{abstract}

Keywords: energy saving; photovoltaic systems; high-efficiency irrigation systems; climate-smart agriculture; water conservation

\section{Introduction}

Agriculture in Punjab accounts for around a quarter of the province's GDP and employs about half of the province's workforce, either directly or indirectly. It also helps to meet $8.0 \%$ of the country's food requirements. In Pakistan, rural people in general, and the agriculture sector in particular, have experienced serious electricity shortages of over $3000 \mathrm{~h}$ per year during recent energy crises [1]. According to assessments, approximately 0.13 million of Punjab's 1.03 million agriculture pumps are connected to the electric grid [2]. In agriculture, diesel engines and prime movers are used to meet the majority of the energy 
requirements for water pumping. The use of diesel in agriculture increased the price of production tremendously. The risk of climate change is increased by greenhouse gas emissions [3]. This problems can be addressed by substituting fossil fuels with renewable power sources and changing the irrigation methods from conventional to efficient and conservation irrigation. The use of innovative and more productive techniques for the efficient use of inputs, particularly water, fertilizers and energy has a significant potential for enhancing agricultural productivity. Pakistan spends roughly fourteen billion USD per year on fuel imports, out of which 21 percent goes to irrigation and agriculture sector [4].

Even though Pakistan has one of the best irrigation systems in the world, there is still a water shortage across the country. To address the problem of water scarcity, the country has installed over one million water tube wells, out of which 82.0 percent are powered by diesel fuel and the remaining by electricity [5]. Water scarcity is a major issue in Pakistan. Similarly, the irrigation system's inefficiency leads to wastage of water resources, resulting a decrease in crop water production [6]. In rural off-grid areas, photovoltaic-powered pumps reduce labour and fuel costs [7].

As daylight is available for more than 300.0 days annually, photovoltaic energy is usually the most cost-effective solution. Photovoltaic-powered water pumping systems are not only environmentally sustainable, but also need low-maintenance and fuel-free [8]. In agricultural, photovoltaic power will help to conserve energy, reduce grid power demand, and promote socioeconomic improvement $[9,10]$. Photovoltaic energy is also less expensive than a traditional diesel irrigation system, allowing farmers in remote areas to access water at a lower cost and improving their socioeconomic and living standards [11,12].

Tamoor et al. [13] investigated the socio-economic and environmental impacts of PV powered HEIS in the Faisalabad. The findings show that PV powered high-efficiency irrigation systems have a significant impact on resource savings, such as energy savings, water usage reduction and labour cost savings, as well as enhanced agricultural yields and farmer benefits, all of which contribute to an improvement in agrarian standard of living.

In 2016-2017, Government of Punjab launched a cost-sharing subsidy scheme for the installation of photovoltaic systems to operate high-efficiency irrigation systems, including drip and sprinkler systems. Farmers contributed $20 \%$ of the cost of photovoltaic systems, while the government subsidized the remaining amount.

\section{Materials and Methods}

Agricultural farms from throughout Punjab province were chosen for the study, which aims to demonstrate the impact of photovoltaic systems operating high efficiency irriga-tion systems across the province. More than two thousand photovoltaic systems have been installed across Punjab province under the subsidy scheme in the last three years, as shown in Figure 1.

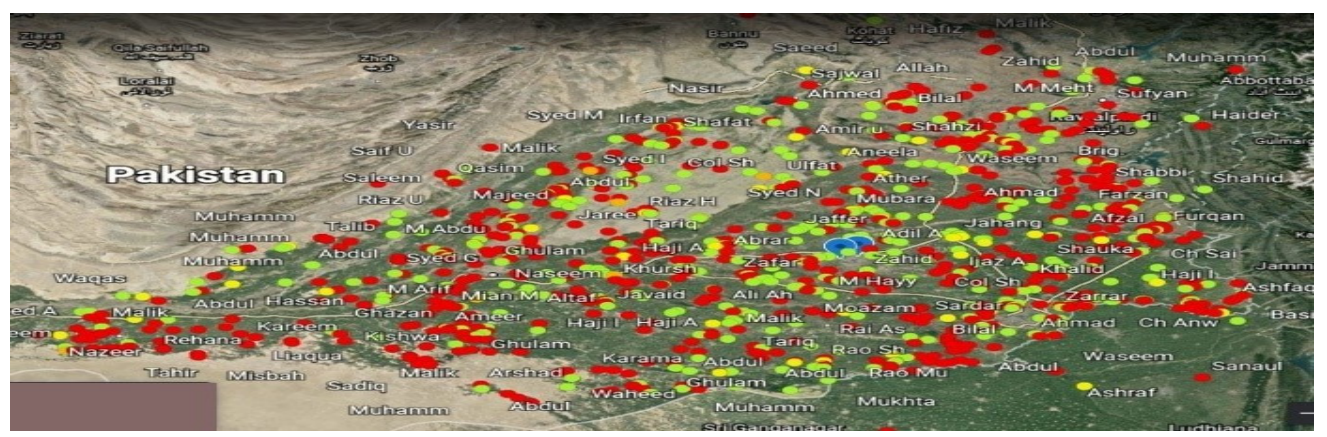

Figure 1. Photovoltaic (PV) and high efficiency irrigation systems (HEIS) installation sites.

A total of 80 agriculture farms were surveyed and categorized, as follows:

(i) Agriculture farms using photovoltaic powered HEIS.

(ii) Agriculture farms using electricity or diesel powered HEIS. 
(iii) Agriculture farmers who use flood irrigation as a method of irrigation were used as a baseline.

More than one-year-old farms were surveyed in this study in order to collect the reliable data throughout the survey. The survey data was analyzed in order to present the findings of the study. The average size of farms utilizing photovoltaic systems was found to be 15 acres. The average capacity of installed PV systems was 9.0 kilowatt, which matched the 7.50 horse power of installed water pumps. On average, the cost of a PV system per acre was calculated to be 0.000142 billion PKR, while the cost per $\mathrm{kWp}$ was calculated to be 0.000149 billion PKR. PV systems were initially more expensive, but their low operating costs made them a viable option for farmers to adopt.

\section{Results and Discussion}

\subsection{PV-Powered HEIS Adoptability}

The government has made efforts hard to promote high efficiency irrigation systems in Punjab province for a long time, but the success rate has not been impressive. For example, from 2011 to 2016, an area of about twenty thousand acres was brought into high efficiency irrigation systems in five years, as shown in Figure 2. High operational expenses of high efficiency irrigation systems have been considered as one of the main obstacles to its adoption and long-term sustainability, mainly for system that are powered by diesel. However, after intervention of photovoltaic system with high efficiency irrigation systems, adoption rate was increased, and twenty thousand acres were brought under high efficiency irrigation systems in only two years.

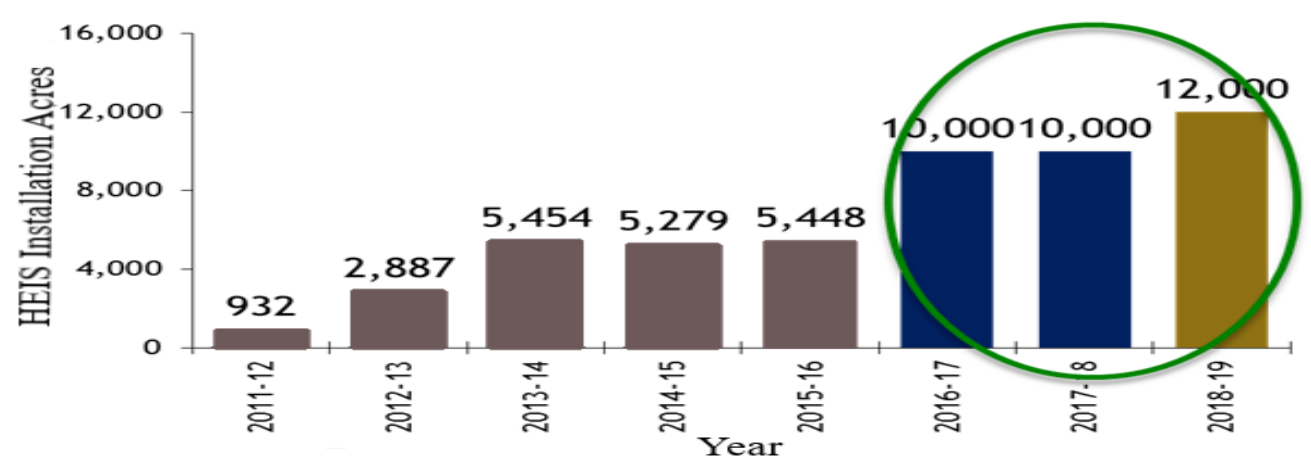

Figure 2. Year-wise adoptability of HEIS before and after PV system interventions.

\subsection{Savings in Energy Cost}

Photovoltaic systems with a capacity of 17.30 megawatt were installed to operate HEIS on about twenty thousand acres as part of this subsidized project, saving 0.0066 billion litres of diesel fuel per year. This fuel savings equates to a 0.726 billion PKR annual reduction in diesel import bills. A cost comparison of solar, diesel, and electricity-powered pumping systems having capacity $7.46 \mathrm{~kW}$ was conducted. The unit cost of PV-powered pumping was discovered to be PKR19.12/kWh, which was 5 percent and 63 percent cheaper than the cost of subsidized electricity and diesel, respectively.

\subsection{Reduction in $\mathrm{CO}_{2}$ Emissions}

Photovoltaic system adoption on a wide scale reduces fossil fuel consumption and, as a result, minimizes the environmental issues associated with fossil fuels. Because 1 litre of diesel releases $2.66 \mathrm{~kg}$ carbon dioxide, replacing diesel powered irrigation with photovoltaic powered irrigation on around twenty thousand acres has resulted in a decrease of $17,556,000 \mathrm{~kg}$ of carbon dioxide emissions per year. 


\subsection{Water Savings in HEIS}

According to primary data analysis, the average annual water consumption per acre for flood irrigation was $5108 \mathrm{~m}^{3}$ and for irrigating through high efficiency irrigation systems it was $2981 \mathrm{~m}^{3}$. Analysis shows that 42 percent water consumption reduced when agriculture land irrigating through high efficiency irrigation systems.

\section{Conclusions}

Results Analysis and findings have shown that PV powered high efficiency irrigation systems provides climate-smart, clean and unique alternative energy sources for irrigation systems in remote areas especially for the areas those are not connected to the national utility grid. This system can bring significant social economic and environmental benefits. Photovoltaic operated high efficiency irrigation systems are helping to stabilize, enhance crop production, and minimize the effect of drought to overcome the pressure of water scarcity during the dry season in developing countries faces serious water shortages, particularly in desert areas. The photovoltaic powered operating high efficiency irrigation systems will motivate the farmers to produce high value crops like vegetables orchards, helping to alleviate poverty in rural areas.

Conflicts of Interest: The authors declare no conflict of interest.

\section{References}

1. Planning and Development Department Government of the Punjab. Punjab Growth Strategy 2018: Accelerating Economic Growth and Improving Social Outcomes. 2015. Available online: https://www.theigc.org/wp-content/uploads/2015/04/ Punjab-Growth-Strategy-2018-Full-report.pdf (accessed on 3 July 2021).

2. Agriculture Statistics of Pakistan. Agriculture Marketing Information Service (AMIS). Directorate of Agriculture (Economics \& Marketing) Punjab, Lahore. 2017. Available online: http:/ / www.amis.pk/agristatistics/statistics.aspx (accessed on 11 July 2021).

3. Schneider, U.A.; Kumar, P. Greenhouse gas mitigation through agriculture. Choices (N. Y.) 2008, 23, 19-23.

4. Siddiqi, A.; Wescoat, J.L., Jr. Energy use in large-scale irrigated agriculture in the Punjab province of Pakistan. Water Int. 2013, 38, 571-586. [CrossRef]

5. Qureshi, A.L.; Lashari, B.K.; Kori, S.M.; Lashari, G.A. Hydro-salinity behavior of shallow groundwater aquifer underlain by salty groundwater in Sindh Pakistan. In Proceedings of the Fifteenth International Water Technology Conference, IWTC-15, Alexandria, Egypt, 31 March-2 April 2011; pp. 1-15.

6. Kim, Y.; Evans, R.G. Software design for wireless sensor-based site-specific irrigation. Comput. Electron. Agric. 2009, 66, 159-165. [CrossRef]

7. Blagbrough, V. Looking Back: The Long-Term Impacts of Water and Sanitation Projects; WaterAid: London, UK, 2001.

8. Foster, R.; Ghassemi, M. Solar Energy: Renewable Energy and the Environment; CRC Press, Taylor \& Francis Group: Boca Raton, FL, USA, 2009; pp. 32-40.

9. Ahmad, S.; Ali, I. Feasibility of Solar Powered Pumping Systems for Deep Tube Wells in Pakistan, Managing Natural Resources for Sustaining Future Agriculture; Research Briefs, Natural Resources Division, Pakistan Agricultural Research Council: Islamabad, Pakistan, 2011; Volume 3.

10. Shouman, E.R.; El-Shenawy, E.T.; Badr, M.A. Economics analysis of diesel and solar water pumping with case study water pumping for irrigation in Egypt. Int. J. Appl. Eng. Res. 2016, 11, 950-954.

11. Cuadros, F.; López-Rodriguez, F.; Marcos, A.; Coello, J. A procedure to size solar-powered irrigation (photoirrigation) schemes. Solar Energy 2004, 76, 465-473. [CrossRef]

12. Mahmoud, E.; El-Nather, H. Renewable energy and sustainable developments in Egypt: Photovoltaic water pumping in remote areas. Appl. Energy 2003, 74, 141-147. [CrossRef]

13. Tamoor, M.; ZakaUllah, P.; Mobeen, M.; Ans-Zaka, M. Solar Powered Automated Irrigation System in Rural Area and their Socioeconomic and Environmental Impact. Int. J. Sustain. Energy Environ. Res. 2021, 10, 17-28. 